ことが示唆された. CNF 充填複合材料に関する研究にお いては，CNFに対する表面処理が機械的特性に及ぼす影 響について検討した事例が報告された。フィラー充填複合 材料に関する研究においては, リサイクル PETを炭化し た炭化フィラー充填複合材料の力学的特性を検討した事例, 導電粒子を添加し電気抵抗率を検討した事例が報告された. 連続繊維強化複合材料に関する研究においては, 連続繊 維の開繊装置を検討した事例, 連続繊維強化熱可塑性樹脂 複合材料成形のための繊維状中間材料の開発に関する事例,
繊維状中間材料を用いた引抜成形における許容未含浸率を 検討した事例が報告された。さらに，連続繊維および不連 続繊維を組み合わせたハイブリッド成形に関する研究事例 が報告され，多くの聴講者にその注目度の高さが示された.

セッション全体では, 会場には多くの聴講者がおり, 質 疑応答においても活発な議論があった.「アロイ・ブレン ド・複合材料」に関わる新材料技術・新成形技術への関心 の高さが伺えており, 今後ますますの発展が期待される.

\title{
アロイ・ブレンド・複合材料 3
}

$$
\text { (F-211 } \mathrm{F}-221)
$$

F-211〜221の「アロイ・ブレンド・複合材料」のセッ ションでは, 11 件の講演があったが, バラエティーに富 んだ内容であり, 纎維強化複合材料に関するものが 3 件, シリカ粒子表面の改質とその複合材料に関する講演が 2 件, ゴム変性ポリアミドと金属との接着強度に関する講演が 1 件，複合フィルムに関する講演が 2 件，ブレンド関連の講 演が 3 件であった.

繊維強化複合材料の講演では, 短繊維強化材の寸法が機 械的性質に与える影響を FEM により検討したものや，ラ ミー紡績糸/PP ストランドの弾性特性を解析により検討し たものがあり, 纎維強化複合材料の機械的性質への様々な 因子の影響を検討したものであった。また，長繊維ペレッ 卜を用いた射出成形品の難燃性について，難燃剤として水 酸化アルミニウムを添加した系での検討結果が報告された。

シリカ粒子は，樹脂系複合材料に様々な機能性を与える ためにしばしば用いられるが，シリカ表面を修飾すること で抗菌性や難燃性の向上を試みた結果が報告された。一般 的に樹脂中にシリカを分散させるためには，表面改質をす ることで親水性のシリカと疎水性の樹脂の濡れ性を改善す る方法がとられるが, 粒子の配列構造を制御することで表

\footnotetext{
* Morii, Tohru

湘南工科大学人間環境学科

藤沢市辻堂西海岸 1-1-25（２51-8511）
}

森井亭*

面改質をすることなく, 樹脂中へナノシリカを均一分散さ せる手法に関する講演があり，従来とは異なるアプローチ で非常に興味深いものであった。

フィルムに関する 2 件の講演は, PVDFにPOSSを複 合化することで赤外線センサ等への応用を目指した耐久性 の改善, カテーテル素材として用いられるウレタンに POSS を複合化させることで耐摩耗性やガスバリア性向上 を図った結果について報告され, 有機, 無機の両方の構造 を持つ POSS の効果が検討されていた.

ブレンド関連の講演では, フッ素系ポリマーの高品質化, 高機能化を目指してフッ素系オリゴマーを微分散させる方 法が提案され, $\mathrm{CO}_{2}$ および $\mathrm{N}_{2}$ を混練雲囲気ガスとして用 いた場合の相容性を検討した結果が報告された。また，他 の樹脂と比較して流動性に劣るポリカーボネートについて, オリゴマーを配合することで流動性改善を検討した結果が 報告され，オリゴマーが表面からスキン層の薄肉領域の流 動性向上に寄与し, ウエルド部の Vノッチ粗さを低下さ せる効果を見出した。最後の講演では，ポリアセタールの 表面光沢を抑制する方法として特殊な有機艶消し剤を用い た結果について検討し，艶消し剤が細かな粒子として均一 分散することで艶消し性と表面平滑性を両立可能であるこ とが報告された。

\section{紡糸・フィルム成形 1 \\ (G-101 G-106)}

今年の秋季大会は繊維産業が盛んな北陸地方での開催と

* Tomiyama, Hideki

秼日本製鋼所広島研究所

広島市安芸区船越南 1-6-1（干736-8602）
いうだけあり，「紡糸・フィルム成形」の一般セッション は初日から 2 日目に渡り非常に多くの口頭発表がエント リーされた。

1 日目は 6 件の発表が行われた。 そのうち延伸装置の 
オーブン特性に関する理論考察が 1 件, フィルムインサー 卜成形時の透明フィルムの成形性に関する評価研究が 1

件, 多層フィルム等による界表面の接着性や強度評価によ る研究が 4 件であった.

オーブン延伸装置では, 熱風の熱伝達性能がフィルム強 度や位相差などの物性に影響するため, その熱量評価を数 值解析的に精度よく推算するための手法提案であった（G -101). 定量的な予測を行うためにはある程度のノウハウ が必要であるが, 比較的高速成形領域においては有効な評 価指針となることが示唆される内容であった. PC/PMMA フィルムインサートの圧空成形では金型の凹型絞り形状へ の賦型性確保が一つのキーファクターであり，その賦型性 について各種圧空条件を変化させた評価検証が行われた (G-102). 結果, PETより賦型性が優れ，またPMMAの ゴム添加量によりその特性が向上することが確認された.

多層 PEフィルムのヒートシールでは, シール温度とその 強度が PE 分子量やシール時間の影響を受けるため, その 要因特性について評価検討が行われた $(\mathrm{G}-103)$. 結果, シール層の分子量が高いとシール温度が高くなることや, シール時間が短いとシール温度が高くなることが判明した。

フィルムの接着性に関する研究報告は, 滅菌紙と CPP フィルムとの熱接合 $(\mathrm{G}-104)$, フッ素系フィルムのレー
ザー溶着（G-105），フィルムインサート成形での成形品 の強度評価（G-106）の 3 件があった。滅菌紙との熱接合 では，リボンヒーターと組紐ヒーターで接合強度の比較を 行っており, 組紐ヒーターを用いた方が高い剥離強度が得 られる結果が報告された。組紐ヒーターはフレキシブル性 の高さから接着面積が稼げた結果によるものと推察される. フッ素系フィルムの溶着では, レーザーの出力による剥離 強度を評価しており, 高出力では界面のガス化が見られる などしたことから, 出力を高めれば接着強度が増すわけで はないことが示唆された。インサート成形における強度評 価では，A-PET・一軸延伸 A-PET・BOPETを用いたそ れぞれの比較を行った。 その結果, 延伸され強度が高まっ たフィルムを用いるほど射出成形品の引っ張り強度が増す データが得られた。ただ，延伸されたフィルムは射出成形 時に熱収縮を伴う可能性があるため, 今後は寸法精度など の評価が必要になる印象である。

以上，初日のフィルムセッションでは成形されたフィル ムを二次加工する際に懸念される事象あるいは特性につい て評価研究を行った内容がほとんどであった。材料開発か ら成形そして二次加工と幅が広い分野であるため, 今回も 聴講して大いに勉強となる内容であった。

\section{紡糸・フィルム成形 2}

$(\mathrm{G}-201 \sim \mathrm{G}-210)$

本セッションは, 二日間に渡って 20 件もの講演が行わ れた.ここ数年の年次大会およびシンポジアでの本セッ ションの発表件数は, 10 件〜 15 件であったことを考慮す ると今回の講演数は関連する研究者としても嬉しい事で あった.ここでは, 大会二日目に発表のあった紡系に関連 する 10 件の講演に関し報告する. 該当する 10 件の講演を 大きく分類すると, 紡糸および延伸における構造解析や結 晶化解析と言った内容に関わる講演が 5 件, ナノファイ バーの製造に関わる内容が 3 件，スパンボンド不織布に関 わる講演が 2 件であった。

構造解析や結晶化解析においては, 従来より広角 $\mathrm{X}$ 線 解析 (WAXD) や示差走査熱量解析 (DSC) 等の分析手 段が汎用的に用いられてきたが，G-202においては50〜 $2,000 \mathrm{~K} / \mathrm{s}$ と言う非常に高速度な昇温下での熱量測定が可 能な高速走査型チップ熱量測定機 (fast scanning chip calorimetry）を適用した結果が報告された. 今後, 結晶化や 緩和挙動の解析に適応が広がることが期待されると同時に 他の観察, 解析方法との組み合わせにより, 従来十分に解 析が出来ていない挙動の解析に適応されて行くのではない かと思われた。また，G-203，G-204においてはLaser 延

\footnotetext{
* Saito, Masaharu

$\mathrm{KB}$ セーレン(侏) 研究開発センター

鯖江市下河端町 6-1-1（广916-0038）
}

伸技術を用いて従来の熱伝導による加熱延伸では達成でき ない繊維形状制御や延伸倍率の拡大による物性改善と言っ た内容が報告された，延伸における単なる加熱方法の置き 換えではない新たな可能性の提案としても興味が持たれた.

ナノファイバーの製造に関わる報告では, 熱にも薬品に も非常に安定な剛直高分子を高温で希薄溶液としたものを 急冷することで結晶化析出させる方法や熱溶融樹脂を細孔 より遠心力を用いて紡系する方法の改良について，更に従 来の電界紡糸（エレクトロスピニング）にエアブローを併 用することで生産性を格段に向上させた場合の物性等につ いての報告がなされた。ナノファイバーの製造においては, 従来, 溶融複合紡系法, メルトブロー法およびエレクトロ スピニング法が中心的に検討されてきていたが，プロセス の改良や製造方法が多様化することで新たな材料のナノ ファイバー化や生産性の向上が期待されると思われた。ナ ノファイバーに関しては, 生産技術の革新・拡充に対し, 用途面での検討がまだまだ遅れているように思われており， 用途開拓に関する研究が期待されるところである.

スパンボンド不織布の製造は，既に技術的にはコモディ ティー化されていると思われていたが, 樹脂側を複合化し 流動特性を変化させたり結晶化挙動をコントロールするこ とで成形性改良（細繊度化や紡糸安定化）や物性改良につ ながることが報告された，不織布としての風合い，柔軟性， 